\title{
KEPUASAN KERJA KADER POSYANDU DI DESA CIHERANG, KECAMATAN DRAMAGA
}

\section{Job Satisfaction of Cadre of Integrated Services Centre (Posyandu) in Ciherang Village, Dramaga Sub District}

\author{
Megawati Simanjuntak ${ }^{1}$, Siti Amanah ${ }^{1}$, Prabowo Tjitropranoto ${ }^{1}$, dan Sri Harijati ${ }^{2}$ \\ ${ }^{1}$ Departemen Sains Komunikasi dan Pengembangan Masyarakat, \\ Fakultas Ekologi Manusia, FEMA - IPB \\ ${ }^{2}$ UPBJJ, Universitas Terbuka Jakarta
}

\begin{abstract}
Posyandu is one of the community participation approach in health sector that is managed by cadres, with the main problem arises is the declining number of visits of mothers of infants and toddlers. The aimed of this research were to analyze the level of job satisfaction of posyandu cadres, and to analyze the factors that influence job satisfaction.Research conducted in Ciherang village with 30 samples that was selected using random sampling. The result showed that most of cadre 's job satisfaction can be categorized high, despite the visit of mother and toddlers tended to decline. It means that the decline was more due to the factor of the target or the mothers themselves, not the factor of posyandu organizers. The higher the incentives received by the cadres and the more participation of cadres in training influenced significantly for the improving of cadre's job satisfaction. In term of the strategies to increase the job satisfaction, in general, all the items associated with the work of posyandu cadres should be retained or categorized low priority, in other words there is no necessary to increase the job satisfaction posyandu cadres.
\end{abstract}

Keywords : Posyandu, Job Satisfaction, Cadre

\begin{abstract}
Abstrak
Posyandu merupakan salah satu pendekatan partisipasi masyarakat dalam bidang kesehatan yang dikelola oleh kader, namun saat ini timbul permasalahan utama yakni menurunnya jumlah kunjungan ibubayi dan balita. Terkait dengan permasalahan tersebut, penelitian ini dilakukan untuk menganalisis tingkat kepuasan kerja kader posyandu, dan faktor-faktor yang mempengaruhi kepuasan kerja. Penelitian dilakukan di Desa Ciherang dengan 30 sampel yang dipilih secara acak. Hasil penelitian menunjukkan bahwa sebagian besar kepuasan kerja kader dapat dikategorikan tinggi, meskipun kunjungan ibu dan balita cenderung menurun. Hal ini dapat dimaknai bahwa penurunan kunjungan adalah lebih karena faktor sasaran atau ibu sendiri, bukan faktor penyelenggara posyandu. Semakin tinggi insentif yang diterima oleh para kader dan semakin sering kader berpartisipasi dalam pelatihan mempengaruhi secara signifikan terhadap membaiknya kepuasan kerja kader. Strategi untuk meningkatkan kepuasan kerja, secara umum, semua hal yang terkait dengan pekerjaan kader posyandu harus dipertahankan atau dikategorikan kedalam prioritas rendah, dengan kata diperlukan lagi upaya untuk meningkatkan kepuasan kerjakader posyandu.
\end{abstract}

Kata Kunci : Kader, Kepuasan Kerja, Posyandu

\section{Pendahuluan}

Posyandu merupakan salah satu bentuk upaya pendekatan partisipasi masyarakat di bidang kesehatan yang dikelola oleh kader Posyandu yang telah mendapatkan pendidikan dan pelatihan dari Puskesmas. Kader Posyandu mempunyai peran yang penting karena merupakan pelayan kesehatan (health provider) yang berada di dekat kegiatan sasaran Posyandu dan memiliki frekuensi tatap muka kader lebihsering daripada petugas kesehatan lainnya (Heru, 2005).

Krisis ekonomi yang melanda Indonesia turut mempengaruhi aktivitas posyandu, hal ini ${ }^{1}$ Korespondensi penulis

E-mail: mega.juntakipb@gmail.com terlihat dengan adanya penurunan aktivitas kader di posyandu dan terlihat dari banyak kader yang drop out. Kurangnya pembinaan, baik dari petugas maupun dari intitusi yang ada di desa, mengakibatkan turunnya aktivitas posyandu di lapangan. Kenyataan ini mengakibatkan keberadaan posyandu makin terpuruk (banyak posyandu yang tidak aktif). Dalam masyarakat muncul berbagai pendapat yang intinya terbagi 2 yaitu: (1) Masyarakat yang merasa bahwa posyandu sudah tidak cocok lagi dan tidak mungkin (sulit) untuk dilaksanakan, dan (2) Masyarakat yang merasa posyandu masih sangat dibutuhkan dan masih banyak cara yang dapat dilaksanakan untuk mengaktifkan posyandu. 
Desa Ciherang merupakan salah satu desa di kecamatan Dramaga dengan jumlah posyandu sebanyak 15 buah dan kader sebanyak 81 orang yang tersebar di 11 RW. Hasil wawancara dengan bidan desa dan pihak puskesmas menunjukkan ada indikasi penurunan jumlah kunjungan ibu-ibu bayi dan balita ke posyandu (Laporan Puskesmas UPT Dramaga tahun, 2011). Penyebab indikasi ini dapat berasal dari ibu sendiri, atau dari faktor luar (eksternal) seperti penyelenggaraan posyandu yang termasuk didalamnya ialah kepuasan terhadap kader pelaksana posyandu. Hal tersebut mendorong dilaksanakannya penelitian ini dengan tujuan untuk melihat bagaimanakepuasan kerja kader posyandu. Kepuasan kerja dari kader posyandu diduga dapat mempengaruhi kunjungan ke posyandu, meskipun dalam penelitian ini tidak akan dilihat kepuasan klien (pengunjung posyandu) terhadap kinerja para kader.

Asumsi yang digunakan dalam penelitian ini adalah kepuasan kerja dari kader posyandu akan sejalan dengan peningkatan kinerja kader seperti ditunjukkan oleh penelitian Puspasari (2002) bahwa terdapat hubungan positif sangat nyata antara kinerja kader dengan keberhasilan Posyandu, pada akhirnya keberhasilan posyandu akan mendorong peningkatan kunjungan sasaran. Disisi lain, faktor internal dan faktor eksternal dari kader posyandu dapat mempengaruhi kepuasan kerjanya. Untuk itu, penelitian membatasi penelitian ini hanya mengkaji kepuasan kerja kader dari sudut pandang kader, tanpa melihat kepuasan dari sudut pandang klien. Adapun fokus penelitian ini adalah menganalisis kepuasan kerja kader posyandu, yang dilanjutkan dengan analisis strategi dalam peningkatan kepuasan kader posyandu dalam melaksanakan tugas-tugasnya.

Tujuan dari penelitian ini adalah untuk (1) menganalisis tingkat kepuasan kerja kader posyandu, dan (2) menganalisis faktor-faktor yang mempengaruhi kepuasan kerja kader posyandu.

\section{Metode Penelitian}

Populasi penelitian ini adalah seluruh kader posyandu yang ada di Desa Ciherangyakni sebanyak 81 orang yang berasal dari 15 posyandu yang tersebar di 10 RW. Sampel ditentukan secara acak dengan jumlah sampel sebanyak 30 kader posyandu yang tersebar di Desa Ciherang. Penelitian dilaksanakan selama 3 bulan yakni pada bulan Oktober sampai Desember 2011 mencakup kegiatan penyelesaian proposal, penyusunan instrumen, pengambilan data, analisis data, dan penulisan laporan.

Penelitian ini merupakan penelitian yang berbentuk explanatory research dengan disain penelitian studi kuantitatif menggunakan metode survey. Dalam penelitian ini terdapat dua peubah, yakni peubah bebas dan peubah terikat. Peubah bebas terdiri atas faktor internal kader (X1) dan faktor eksternal kader (X2), sedangkan peubah terikat adalah kepuasan kerja kader posyandu (Y1). Faktor internal kader terdiri dari: usia (X11), jumlah anggota keluarga (X12), tingkat pendidikan (X13), status perkawinan (X14), adanya anak balita (X15), status pekerjaan (X16), motivasi menjadi kader (X17), lama menjadi kader (X18) dan dukungan keluarga (X19). Faktor eksternal kader terdiri dari: insentif yang diterima (X21), pelatihan yang pernah diikuti (X22), dan dukungan tokoh masyarakat (X23). Kepuasan kerja kader posyandu terdiri dari: kepuasan terhadap tugas persiapan posyandu (Y11), kepuasan terhadap pelaksanaan posyandu (Y12), dan kepuasan terhadap tugas evaluasi posyandu (Y13).

Dalam penelitian ini kepuasan kerja kader diukur dengan menilai tingkat kepuasan kerja kader berdasarkan uraian tugasnya di Posyandu. Tugas kader terdiri dari 3 (tiga) kelompok yaitu tugas persiapan sebelum hari H Posyandu, kegiatan utama pada hari $\mathrm{H}$ Posyandu dan kegiatan setelah hari $\mathrm{H}$ Posyandu. Keseluruhannya terdapat 23 pertanyaan dan masing-masing diberi nilai 4 jika sangat puas, 3 jika puas, 2 jika kurang puas dan 1 jika sangat tidak puas sehingga diperoleh skor maksimum dari semua pertanyaan adalah 60. Selanjutnya kepuasan kerja kader dikategorikanmenjadi 2 kelompok yaitu puas apabila total skor $60 \%$ ke atas dan dikategorikan tidak puas apabila total skor $<60 \%$.

Nilai validitas kepuasan kerja kader posyandu berkisar antara 0,294 hingga 0,818, sedangkan nilai reliabilitas sebesar 0,933 . Artinya instrumen yang digunakan termasuk sangat reliabel. Pengolahan data dibagi menjadi dua yakni statistika deskriptif dan statistika induktif (inferensial). Statistika deskriptif yang digunakan mencakup: rata-rata, simpangan baku, maksimum dan minimum digunakan untuk semua data kuantitatif. Analisis regresi berganda digunakan untuk mengetahui faktor-faktor yang 
mempengaruhi kepuasan kerja kader posyandu.

\section{Hasil dan Pembahasan}

\section{Karakteristik Internal Kader Posyandu}

Kegiatan posyandu masih sangat tergantung pada kader posyandu, keberadaan kader posyandu dibutuhkan sebagai salah satu sistem penyelenggaraan pelayanan kebutuhan akan kesehatan dasar. Kader posyandu merupakan ujung tombak dari pelayanan kesehatan yang merupakan kepanjangan tangan dari puskesmas. Dalam penelitian ini hampir dua pertiga kader yang menjadi contoh berusia di atas 35 tahun dengan rataan $41,87+10,71$ tahun. Artinya rata-rata contoh adalah masuk kategori usia produktif (Tabel 1). Selanjutnya, setengah contoh memiliki tingkat pendidikan kader tamatan SLTP dan SLTA dengan rata-rata lama pendidikan $8,63+3,65$. Hal ini berarti tingkat pendidikan contoh secara umum adalah masuk kategori pendidikan dasar.

Besar keluarga adalah jumlah seluruh anggota keluarga yang tinggal bersama dalam satu rumah. Besar keluarga menurut BKKBN (1998), dikategorikan menjadi tiga kelompok yaitu kecil ( $\leq 4$ orang), sedang (5-7 orang) dan besar ( $>7$ orang). Sebagian besar kader telah menikah dan sekitar sepertiganya mempunyai balita, dengan jumlah balita adalah 1 anak. Keberadaan balita merupakan tanggung jawab keluarga yang harus dilakukan kader. Hasil studi Beham et al. (2010) mengindikasikan keseimbangan antara pekerjaan dan keluarga berpengaruh terhadap kepuasan kerja.

Rata-rata jumlah anggota keluarga adalah $5,47+2,76$ dengan kisaran antara 2 orang hingga 11 orang anggota dalam satu rumah tangga. Terakhir, lebih dari setengah contoh memiliki pekerjaan tetap selain sebagai kader (Tabel 1). Adanya pekerjaan lain tentu akan membuat kader posyandu harus mampu mengalokasikan waktu sebaik mungkin untuk kegiatan posyandu dan pekerjaannya.

Lebih dari separuh motivasi menjadi kader posyandu dari responden adalah keinginan untuk menolong masyarakat. Hal ini sejalan dengan salah satu dari 7 kriteris kriteria yang harus dipenuhi oleh seorang kader seperti tercantum dalam Instruksi Menteri Dalam Negeri Tahun 1990 tentang peningkatan pembinaan mutu Pos Pelayanan Terpadu (Posyandu), yakni: (1) Dapat membaca dan menulis; (2) Berjiwa sosial dan mau bekerja sama secara relawan; (3) Mengetahui adat istiadat serta kebiasaan masyarakat; (4) Mempunyai waktu yang cukup; (5) Bertempat tinggal di wilayah Posyandu; (6) Berpenampilan ramah dan simpatik; dan (7) Diterima masyarakat setempat (Tabel 2).

Rata-rata contoh menjadi kader adalah 9 tahun dengan kisaran antara 0,08 hingga 26 tahun. Data ini menunjukkan bahwa kader sudah cukup berpengalaman dalam mengelola posyandu yang menjadikan seluruh keluarga mendukung contoh menjadi kader (Tabel 2). Meskipun Nestor dan Leary (2000) tidak menemukan bahwa seiring dengan meningkatnya pengalaman kerja penyuluh, kepuasan intrinsik atau ekstrinsiknya akan meningkat.

\section{Karakteristik Eksternal Kader Posyandu}

Seluruh kader memperoleh insentif yang besarnya berbeda-beda antar kader (Tabel 3). Kisarannya adalah antara $\mathrm{Rp} 6.666$ hingga $\mathrm{Rp}$ 100.000 per orang per bulan, namun yang paling banyak adalah sebesar Rp 20.000 per orang per bulan. Jumlah ini dianggap kurang memadai oleh sebagian besar kader sehingga diusulkan agar besarnya insentif dapat dinaikkan menjadi Rp 300.000 per orang per bulan oleh sekitar dua per tiga kader dan sisanya menyarankan insentif sebesar Rp 100.000 per orang per bulan. Hasil wawancara mendalam juga mengindikasikan insentif yang diterima masih sangat kurang dibandingkan dengan banyaknya kerja yang dilakukan. Para kader berharap meskipun perannya sebagai tenaga sukarela, namun dapat memperoleh penghargaan yang lebih layak.

Hasil temuan penelitian ini sejalan dengan temuan penelitian dari Oloruntoba dan Ajayi (2003) yang menyatakan bahwa hanya $10 \%$ responden yang sangat puas dengan sistem reward yang berlaku. Sementara responden yang tidak puas dengan sistem reward adalah 58,9\%, yang merupakan indikasi bahwa para karyawan umumnya tidak puas dan dapat mempengaruhiproduktifitasnya seperti dinyatakan oleh Odugbesan (1985), Greson and Livesey (1986). Tidak ada hubungan yang signifikan $(\mathrm{p}=0,05)$ antara karakteristik sosial ekonomi dan motivasi karyawan (Oloruntoba \& Ajayi, 2003).Hasil ini sejalan dengan temuan Eric (1995) bahwa faktor yang berhubungan pekerjaan adalah prediktor yang lebih baik untuk kepuasan kerja daripada karakteristik sosial ekonomi. Selanjutnya sebagian besar kader menyatakan pernah mengikuti pelatihan yang terkait dengan posyandu. 
Tabel 1 Karakteristik Internal Kader Posyandu

\begin{tabular}{lc}
\hline \multicolumn{1}{c}{ Peubah } & Persentase \\
\hline Usia kader (tahun) & \\
1. $<25$ tahun & 0,0 \\
2. 25 - 35 tahun & 30,0 \\
3. > 35 tahun & 70,0 \\
Tingkat pendidikan kader & \\
1. Tidak Sekolah & 3,3 \\
2. Tidak Tamat SD & 3,3 \\
3. Tamat SD & 36,7 \\
4. Tamat SLTP & 20,0 \\
5. Tamat SLTA & 30,0 \\
6. Diploma/Sarjana & 6,7 \\
Satus perkawinan & \\
1. Belum Menikah & 3,3 \\
2. Menikah & 93,3 \\
3. Janda & 3,3 \\
Ada anak balita yang harus diasuh oleh kader & \\
1. Tidak mempunyai balita & 70,0 \\
2. Mempunyai balita & 30,0 \\
Jumlah Anggota Keluarga & \\
< 4 orang & 46,7 \\
5-6 orang & 23,3 \\
7-8 orang & 13,3 \\
> orang & 16,7 \\
1. Bekerja & \\
2. Tidak bekerja & 43,3 \\
\hline & 56,7 \\
\hline
\end{tabular}

Adapun jenis pelatihan yang pernah diikuti adalah pelatihan gizi, KB, imunisasi, kesehatan lingkungan, PIN, keorganisasian, kesehatan, lansia, dan PHBS. Semua kader yang pernah mengikuti pelatihan menyatakan memperoleh mafaat dari pelatihan tersebut. Terkait dengan dukungan dari tokoh masyarakat, sebagian besar kader menyatakan ada dukungan yang diberikan oleh tokoh masyarakat dan dukungan tersebut juga sangat berguna bagi keberlangsungan posyandu (Tabel 3).

Adapun bentuk dukungan dari tokoh masyarakat yang diberikan adalah bantuan makanan untuk kader dan biaya tambahan untuk membeli PMT, bantuan tenaga, berkunjung, memotivasi, dan juga membantu menginformasikan kepada posyandu. Dukungan sangat diperlukan oleh kader untuk meningkatkan motivasi kerja agar tercapainya peningkatan kinerja menjadi lebih baik, mengingat bahwa kader melaksanakan tugasnya dengan sukarela. Dukungan tokoh masyarakat dapat meningkatkan kepercayaan diri kader dalam melaksanakan tugas-tugasnya.

\section{Pelaksanaan Posyandu}

Salah satu peran dari para kader dalam setiap kegiatan posyandu adalah melakukan penyuluhan bersama dengan petugas kesehatan. Hasil penelitian menunjukkan bahwa materi penyuluhan yang diberikan kepada para ibu adalah tentang ibu hamil, imunisasi, kesehatan lingkungan, KB, kesehatan dan gizi ibu anak, masalah nyamuk, sampah, diare, penimbangan, vitamin, KMS, pentingnya pemeriksaan anak ke posyandu, PMT, bahaya penyakit kaki gajah, dan PIN. Metode penyuluhan yang diterapkan adalah dengan dengan kunjungan langsung ke rumah, dikumpulkan dalam satu tempat,langsung ketika posyandu, melalui speaker mesjid, dan memanfaatkan event kompleks. Namun metode paling banyak dilakukan adalah dengan 
Tabel 2 Sebaran Motivasi, Lama Menjadi Kader dan Dukungan Keluarga

\begin{tabular}{lr}
\hline \multicolumn{1}{c}{ Peubah } & Persentase \\
\hline Motivasi menjadi kader posyandu (jawaban dapat lebih dari satu) \\
1. Insentif & 0,0 \\
2. Tanggung jawab & 10,0 \\
3. Menolong masyarakat & 56,7 \\
4. Senang dengan anak kecil & 6,7 \\
5. Menambah pengalaman & 16,7 \\
6. Terpaksa karena tidak ada yang mau & 6,7 \\
7. Ada yang mengajak & 6,7 \\
8. Ibadah & 3,3 \\
9. Silaturahmi & 3,3 \\
Lama menjadi kader & \\
1. < 5 tahun & 40,0 \\
2. 5 - 10 tahun & 20,0 \\
3. 10 tahun & 40,0 \\
Dukungan keluarga & \\
1. Mendukung & 100,0 \\
2. Kurang mendukung & 0,0 \\
3. Tidak mendukung & 0,0 \\
\hline
\end{tabular}

kunjungan ke rumah. Tempat pelaksanaan posyandu biasanya adalah di rumah kader, rumah bidan, rumah RT ataupun di bangunan posyandu yang sengaja dibangun oleh masyarakat. Namun yang terbanyak adalah di rumah kader. Waktu pelaksanaan posyandu biasanya adalah 1 bulan sekali dari jam 9 sampai jam 11. Berdasarkan hasil wawancara dengan para kader rata-rata jumlah kunjungan ke posyandu untuk ibu hamil adalah 51,4 ibu dan balita, ibu hamil sebesar 5,42 dan ada kunjungan lansia pada 2 posyandu sejumlah 15 orang.

Beberapa kendala yang ditemukan oleh kader dalam pelaksanaan posyandu adalah PMT terbatas, kurang bantuan, kurang sadarnya para ibu tentang pentingnya posyandu dan imunisasi pada anak sehingga ketika pelaksanaan posyandu hanya sedikit ibu yang datang, tidak ada dukungan lain selain keluarga masyarakat sulit diajak, banyaknya laporan, memberi rujukan ke rumah sakit agak dipersulit meskipun masyarakat telah memiliki jamkesmas, banyak anak yang takut diimunisasi karena takut disuntik, pendataan per tahun didanai kecil hanya Rp 25.000, dan sulit mengajak ibu-ibu yang lebih percaya pada dokter. Solusi yang dilakukan adalah membuat uang kas rutin dimana setiap ibu wajib membayar, kader dan masyarakat (ibu lurah/RT) ikut menyampaikan informasi pentingnya kegiatan posyandu, memberikan penjelasan dan pengertian pada masyarakat dengan sabar, diserahkan tugas mengantar masyarakat yang sakit ke rumah sakit kepada yang berpengalaman saja, berkumpul dengan sesama kader, anak yang takut disuntik biasanya diberikan PMT terlebih dahulu, mendatangi ibuibu langsung ke rumah, pembagian tugas lebih merata, lebih gencar lagi melakukan penyuluhan tentang posyandu, membangun kerjasama antara masyarakat dan kader dan melakukan studi banding dan kelengkapan fasilitas posyandu.

\section{Tingkat Kepuasan Kerja Kader Posyandu}

Pada Gambar 1 disajikan kategori tingkat kepuasan kader terhadap pelaksanaan posyandu. Sebagian besar kader merasa puas terhadap kinerja posyandu yang telah dilakukannya. Dengan demikian, jika dihubungkan dengan permasalahan penelitian ini yakni semakin rendahnya tingkat kunjungan ibu-ibu, tidak sejalan dengan kepuasan kerja yang dirasakan oleh kader yang merasa puas dengan kinerjanya. Hasil penelitian ini sejalan dengan studi Long dan Swortzel (2007) serta Ibrahim, Muhammad, Yahaya, Luka, dan Nasarawa (2008) yang menyatakan bahwa sebagain besar penyuluh merasa puas terhadap kerjanya. 
Tabel 3 Sebaran Contoh Berdasarkan Adanya Insentif, Paritsipasi dalam Pelatihan dan Dukungan Tokoh Masyarakat

\begin{tabular}{lr}
\hline \multicolumn{1}{c}{ Peubah } & Persentase \\
\hline Insentif & 100,0 \\
1. Ada & 0,0 \\
2. Tidak ada & \\
Besar insentif & 6,7 \\
1. Memadai & 93,3 \\
2. Tidak memadai & \\
Ikut pelatihan & 90,0 \\
1. Pernah ikut & 10,0 \\
2. Tidak pernah ikut & \\
Manfaat pelatihan terhadap kinerja kader & 100.0 \\
1. Bermanfaat & 0,0 \\
2. Tidak bermanfaat & \\
Dukungan tokoh masyarakat & 86,7 \\
1. Mendukung & 3,3 \\
2. Kurang mendukung & 10,0 \\
3. Tidak mendukung & \\
Manfaat dukungan tokoh masyarakat terhadap kinerja kader & 100.0 \\
1. Bermanfaat & 0,0 \\
2. Tidak bermanfaat &
\end{tabular}

\section{Faktor-faktor yang Mempengaruhi Kepuasan Kerja Kader Posyandu}

Untuk menganalisis faktor-faktor yang ikut mempengaruhi kepuasan kerja para kader posyandu digunakan metode analisis regresi liner berganda Backward (Gambar 2). Dari 10 buah model yang dihasilkan, dipilih model yang ke delapan, dengan pertimbangan ada 2 peubah yang memiliki pengaruh yang signifikan dan besarnya pengaruh adjusted $R$ square, yakni besar insentif dan pernah tidaknya kader mengikuti pelatihan kader. Hasil penelitian ini sejalan dengan studi Mc Caslin dan Mwangi (1994) dan Mowbray (2002) yang menyatakan bahwa insentif bekerja berpengaruh terhadap kepuasan kerja, demikian pula keikutsertaan dalam pelatihan berpengaruh terhadap kepuasan kerja berdasarkan studi Ibrahim et al. (2008).

Pada model kedelapan, Koefisien R kuadrat (koefisien determinasi) dari faktor-faktor jumlah anggota keluarga, status kerja, insentif dan pernah tidaknya mengikuti pelatihan adalah 0,245 atau $24,5 \%$. Artinya, besarnya pengaruh langsung faktorfaktor tersebut secara bersama-sama terhadap kepuasan keja kader posyandu adalah sebesar 0,245 atau $24,5 \%$. Adapun sisanya, yaitu 75,5\% dijelaskan oleh faktor-faktor yang lain di luar model. Persamaan regresi bergandanya adalah : Y1 $=73,053+0,964$ $X_{12}+4,406 X_{16}+0,000 X_{21}-14,572 X_{22}$.

Faktor-faktor yang berpengaruh dan besarnya pengaruh secara sendiri-sendiri (parsial) terhadap kepuasan kerja kader posyandu dilihat dari koefisien Beta (koefisien regresi yang sudah distandarisasi), disajikan pada Gambar 2. Temuan penelitian ini memberikan implikasi bahwa kepuasan kerja kader posyandu dapat diperbaiki dengan meningkatkan insentif dan memperbanyak pelatihan untuk kader. Karakteristik internal kader posyandu seperti jumlah anggota keluarga, tingkat pendidikan formal, umur, lama menjadi kader tidak berpengaruh signifikan terhadap kepuasan kerja kader posyandu. Artinya, karakteristik para kader belum berperan terhadap kepuasan kerja atau sebaliknya kepuasan kerja kader belum memperhatikankarakteristik kader.

Jika dicermati dari model regresi yang diperoleh, status perkawinan tidak berhubungan dengan kepuasan kerja penyuluh, dimana penelitian ini konsisten dengan studi lainnya (Herzberg et al., 1957). Namun demikian, beberapa studi lainnya menyatakan sebaliknya, yakni ada hubungan antara 
status perkawinan dengan kepuasan kerja, hal ini mengindikasikan bahwa penyuluh yang menikah atau telah bercerai lebih puas dengan pekerjaannya dibandingkan penyuluh yang menikah kembali, tidak pernah kawin, atau janda (Bowen et al., 1994; Fetsch \& Kennington 1997). Pendidikan penyuluh tidak signifikan hubungannya dengan kepuasan kerja penyuluh sejalan dengan hasil penelitian Bowen et al., (1994), Cano \&Miller, (1992a), Cano dan Miller (1992b), Castillo \& Cano (1999), Castillo et al., (1999), Griffin (1984), Herzberg et al., (1957). Umur juga tidak berhubungan dengan kepuasan kerja penyuluh yang sejalan dengan hasil beberapa studi (Cano \& Miller 1992a; Cano \& Miller 1992b; Castillo \& Cano 1999; Castillo et al., 1999).Juga, tidak ada hubungan yang signifikan antara karakteristik pribadi penyuluh (jenis kelamin, usia, status perkawinan dan tingkat pendidikan) dengan tingkat kepuasan kerja (Banmeke\&Ajayi, 2005). Terakhir, Nestor dan Leary (2000) tidak menemukan bahwa seiring dengan meningkatnya pengalaman kerja penyuluh, kepuasan intrinsik atau ekstrinsiknya akan meningkat.

\section{Kesimpulan}

Kepuasan kerja dari para kader posyandu dapatdinyatakan masih tinggi, meskipun kunjungan ibu dan balita cenderung menurun. Artinya penurunan tersebut lebih disebabkan oleh faktor sasaran atau para ibu sendiri bukan faktor penyelenggara posyandu. Semakin tinggi insentif yang diterima oleh kader dan pernah tidaknya kader mengikutipelatihan memberikan pengaruh dalam meningkatkan kepuasan kerja kader posyandu. Terkait strategi peningkatan kepuasan, secara umum semua item yang terkait dengan kerja kader posyandu tergolong harus dipertahankan atau prioritas rendah, dengan kata lain tidak diperlukan upaya peningkatan kepuasan kader posyandu.

\section{Daftar Pustaka}

Banmeke, T.O.A. and Ajayi, M.T. 2005. Job Satisfaction of Extension Workers in Edo State Agricultural Development Programme (EDADP), Nigeria. Inf. J. Agric. Rural Dev., 2005, 6: 202 - 207. http://www.ajol.info/index. php/ ijard/article/view/2610/11232

[BKKBN] Badan Koordinasi Keluarga Berencana
Nasional. (1998). Undang-Undang RI No,10 Tahun 1992 tentang Perkembangan Kependudukan dan Pembangunan Keluarga Sejahtera. Jakarta: Badan Koordinasi Keluarga Berencana Nasional.

Bowen, C. F., Radhakrishna R., \& Keyser R. 1994. Job satisfaction and commitment of 4-H agents. Journal of Extension [Online]. 32(1). Diunduh melalui <http://www.joe.org/joe/1994june/rb2. html>.

Cano, J., \& Miller, G. 1992b. A gender analysis of job satisfaction, job satisfier factors, and job dissatisfier factors of agricultural education teachers [Electronic version]. Journal of Agricultural Education, 33(3), 40-46.

Castillo, J. X., \& Cano, J. (1999). A comparative analysis of Ohio agriculture teachers' level of job satisfaction [Electronic version]. Journal of Agricultural Education, 40(4), 67-76.

Castillo, J. X., Conklin, E. A., \& Cano, J. (1999). Job satisfaction of Ohio agricultural education teachers [Electronic version]. Journal of Agricultural Education, 40(2), 19-27.

Fetsch, R. J., \& Kennington, M. S. (1997). Balancing work and family in Cooperative Extension: History, effective programs, and future directions. Journal of Extension, 35(1). Retrieved September 9, 2003, from http://www. joe.org/joe/1997february /a2.html

Gregson, S., \& Liversey, F. 1986. Management and the Organization. London ELBS/Heineman.

Griffin, S. F. (1984). Methods of coping with work force role conflict in relation to job satisfaction of Cooperative Extension home economists (Doctoral dissertation, Rutgers University, 1984). Summary of Research in Extension, 2, 195.

Heru, AS. 2005. Kader Kesehatan Masyarakat. Jakarta: EGC.

Herzberg, F., Mausner, B., Peterson, R. O., \& Capwell, D. F. (1957). Job attitudes: Review of research and opinion. Pittsburgh, PA: Psychological Service of Pittsburgh.

Ibrahim, H., Muhammad, D. M., Yahaya, H and Luka, E.G, Nasarawa. 2008. Role Perception and Job Satisfaction Among Extension Workers In Nasarawa Agricultural Development Programme (NADP) of Nasarawa State, Nigeria. PAT 2008; 4 (1): 62-70: ISSN: 0794-5213. 
Online copy available at www.patnsukjournal. com/currentissue

Long, J.L., \& Swortzel, K.A. 2007. Factors influencing job satisfaction of Extension agents in the Mississippi State University Extension Service. http://www.joe.org/joe/2011 april/rb1. php - 32k

McCaslin, N. L. dan Mwangi, J. 1994. Job Satisfaction of Kenya's Rift Valley Extension Agents. October 1994 // Volume 32 // Number 3 // Research in Brief // 3RIB1. http://www.joe. org/joe.

Mowbray, J. M. (2002). Factors affecting turnover of county Extension agents in the University of Kentucky Cooperative Extension Service. Dissertation Abstracts International, 63(02), 465A. (UMI No. 3042470)

Nestor, P. I., \& Leary, P. 2000. The relationship between tenure and non-tenure track status of Extension faculty and job satisfaction. Journal of Extension, 38(4), Article 4RIB1. Available at:http://www.joe.org/ 2000august.rbi.html

Odugbesan, A. O. 1985. Motivation: A management tool. Perman Journal, 12 (1), 13 - 14

Oloruntoba, A \& Ajayi, M.T. 2003. Motivational Factors and Employees' Job Satisfaction in Large-Scale Private Farms in Ogun State, Nigeria. Volume 10, Number 1 Spring 2003 67. http://www.aiaee.org/attachments/ 228 Oloruntoba-Vol-10,1-9.pdf.

Puspasari, A. 2002. Faktor-faktor yang Mempengaruhi Kinerja Kader Posyandu di Kota Sabang Propinsi Nanggroe Aceh Darussalam. [Skripsi]. Bogor: Jurusan Gizi Masyarakat Dan Sumberdaya Keluarga, Fakultas Pertanian Institut Pertanian Bogor. 